\title{
Short Communication: Morphological characteristics and morphometric of Stingless Bee (Apidae: Hymenoptera) from Banten Province, Indonesia
}

\author{
ADE EFIN, TRI ATMOWIDI", TARUNI SRI PRAWASTI \\ Department of Biology, Faculty of Mathematics and Natural Sciences, Institut Pertanian Bogor. Jl. Raya Dramaga, Kampus IPB Dramaga, Bogor 16680, \\ West Java, Indonesia. Tel./fax.: +62-251-8622833. `email: atmowidi@ apps.ipb.ac.id \\ Manuscript received: 5 May 2019. Revision accepted: 24 May 2019.
}

\begin{abstract}
Efin A, Atmowidi T, Prawasti TS. 2019. Short Communication: Morphological Characteristics and Morphometric of Stingless Bee (Apidae: Hymenoptera) from Banten Province, Indonesia. Biodiversitas 20: 1693-1698. Tetragonula (Meliponini: Apidae) belong to stingless bees that characterized by complex communication, permanent colonies with division of castes, i.e., queen, males, and workers. This paper described morphological characters and morphometric study of stingless bee from Pandeglang, Banten Province, Indonesia. Local people (Sundanese) known as the specimen examined is "teuweul omas" that have different in nest entrance characteristics compare to nest of Tetragonula laeviceps found commonly. In average, specimens examined were $4.445 \pm 0.072 \mathrm{~mm}$ body length, $1.911 \pm 0.019 \mathrm{~mm}$ head width, mesoscutum has distinct hair bands separated by glabrous interspaces area, with plumose frontal hairs, and black metasoma, legs, and hairs on the frontal. Male genitalia of stingless bee examined are long gonostylus and slender with sparse hairs at apex, penis valve is very robust, tapering at the apex and shorter than gonostylus. Based on morphological characteristics and morphometric measurements, we identified the specimen examined is Tetragonula cf. laeviceps.
\end{abstract}

Keywords: Morphometric, stingless bee, Tetragonula cf. laeviceps

\section{INTRODUCTION}

Stingless bees (Apidae: Meliponinae) are eusocial insects living together in a colony with a highly organized system (Michener 2007). They have complex communication, build permanent colonies, and maintain a division of caste, i.e., queen, males, and workers. Queen body size is larger than males and workers, and the workers are generally smaller than the males. In the world, stingless bees consist of more than 500 species (Michener 2013). Stingless bees have strong mandibles to defend and protect their colony from predators. They use propolis (bee-glue) to build the beehives and to protect against pathogens. Stingless bees are important pollinators in various plant species (Slaa et al. 2006).

Tetragonula is one genus of stingless bees. In Indonesia, stingless bees are known as klanceng or lanceng (East and Central Java), teuweul (West Java), galo-galo (Sumatra), kelulut (Kalimantan), and ketape or emmu (Sulawesi). Distribution of stingless bees are in the neotropical regions (from Mexico to Argentina), IndoAustralian regions (India, Sri Lanka, Taiwan, Solomon Islands, the southern part of Indonesia, and New Guinea), and Australian region (Michener 2007). Nesting sites of most species of stingless bees are in the hollow of trees or human houses, particularly eaves, pillars of wooden houses (Sakagami 1983), bamboos (Starr and Sakagami 1987), and in the ant nest (Sakagami et al. 1989).

In this study, we described morphological characteristics and morphometric of stingless bee from
Ciomas area in Banten Province, Indonesia. Local people (Sundanese) known the stingless bee as "teuweul omas".

\section{MATERIALS AND METHODS}

\section{Collection and preservation of specimens}

Samples of stingless bee were obtained from an apiary in Baranangsiang Indah, Bogor, West Java, Indonesia $\left(6^{\circ} 36^{\prime} 49.3^{\prime \prime} \mathrm{S}, 106^{\circ} 49^{\prime} 29.2^{\prime \prime} \mathrm{E} ; 329 \mathrm{~m}\right.$ asl). Based on the information from the own apiary, the stingless bee colonies examined were taken from Ciomas, Pandeglang, Banten Province. Thirty individuals of worker and two individuals of male were taken from the colony and then preserved in $70 \%$ ethanol solution for morphometric measurement and identification process. Identification and measurement of morphometrics were conducted in the Laboratory of Animal Biosystematics and Ecology, Department of Biology, Faculty of Mathematics and Natural Sciences, IPB University (Bogor Agricultural University), Bogor, Indonesia.

\section{Specimen identification and morphometrics measurement}

Bee specimens were identified based on morphological characters and morphometric measurements as described by Sakagami (1978), Sakagami and Inoue (1987), and Sakagami et al. (1990). Morphometric measurements were performed using a stereomicroscope Nikon Model C-LEDS mounted with Optilab viewer and Image Raster software. 
Morphometric of stingless bee measured consist of body length (BL), head width (HW) (Sakagami 1978), head length, clypeus length, lower and upper interocular distance, interantennal distance, antennocellar distance, antennocular distance (modification of Michener 2007), length and width of eyes (EL and EW), maximum and lower interorbital distances (MOD and LOD), interocellar distance (IOD), ocellocular distance (OOD), maximum width of gena (GW), minimum malar length (ML), length and width of flagellomere IV (FL and FW) (Sakagami 1978), length and width of mandible teeth, length and width of mesoscutum (Rasmussen 2013), length of forewing including tegula (WL1), distance between $M-C u$ bifurcation and basal tip of marginal cell (WL2) (Sakagami 1978), length and width of forewing, length and width of hindwing, hamuli number (Klakasikorn et al. 2005), hind tibia length (HTL), maximum width of hind tibia and hind basitarsus (HTW and HBW) (Sakagami 1978), and femur length and hind basitarsus (Klakasikorn et al. 2005). Morphology of male genitalia organ and nest structure of stingless bee also observed and described to support species identification. Morphological characters of worker and male of stingless bee were described.

\section{RESULTS AND DISCUSSION}

Worker of stingless bee examined are characterized by body predominantly black (Figure 1). The measurement of the characters is presented in Table 1. Clypeus is blackishbrown to black with covered by silver to dark brown hairs. Ocellar area is with simple hairs, scape or antenna base is testaceous (brick red, brownish red or brownish yellow) to ferruginous (rust-colored, reddish brown), antennae are with 10 flagellomere, dark brown to black color. Malar space is shorter than flagellomere width and length of flagellomere IV is shorter than their width (Figure 2.A). Width of genna is narrower than the width of eye and mandible with two teeth (Figure 2.C). While, the male of stingless bee examined is predominantly dark (Figure 1), hind tibia with not plumose hairs, abdomen is blackish brown, trochanter is darker and scape is ferruginous. Morphometrics of worker stingless bee are body length (4.764-4.811 mm), WL $14.353-4.435 \mathrm{~mm}), \mathrm{WL}_{2}$ (1.212$1.283 \mathrm{~mm})$, HTL (1.462-1.472 mm), HTW (0.482 mm), 5 hamuli in hind wings, HW (1.802-1.837 mm), EL (1.295$1.304 \mathrm{~mm})$, FL (0.181 mm), FW (0.156-0.161 mm), MOD (1.120-1.140 mm), and LOD (0.748-0.753 mm) (Table 1), antennae with ferruginous scape and eleven segments of flagellomere (Figure 2.D). The results of the measurements of worker stingless bee of this study are similar to other related references (Sakagami 1978; Karimah 2017; Manarudin 2019) which observed Tetragonula laeviceps. Ratio of several characters of worker stingless bee examined also similar with other related references, such as WL2/HW, HTL/HW, EL/MOD, LOD/MOD, GW/EW, HTW/HTL, and HBW/HTW (Table 2). Based on morphological characters and morphometric measurements, we identified the specimen is Tetragonula cf. laeviceps. In addition, the T. laeviceps described by Manarudin (2019) is collected from Pandeglang, Banten that has a wide diameter of nest entrance.

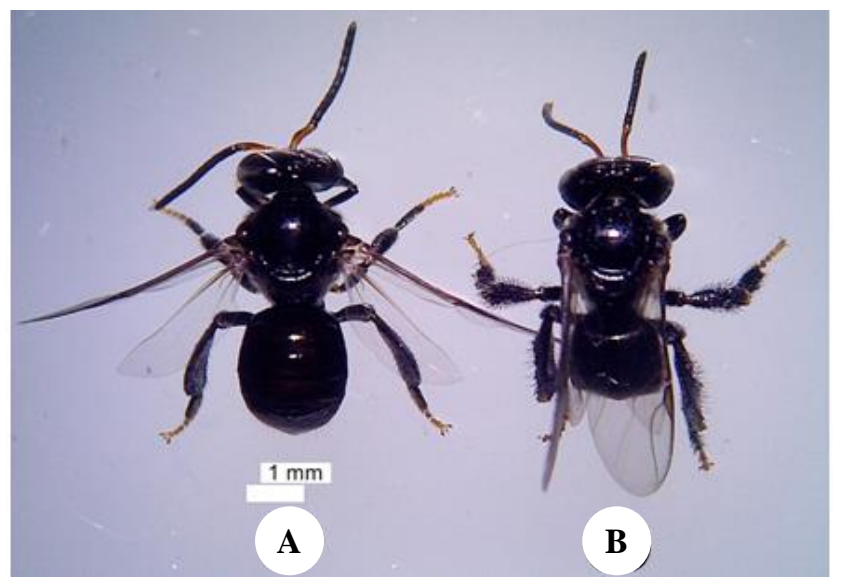

Figure 1 Male (A) and worker (B) of Tetragonula laeviceps from Pandeglang, Banten Province. Scale bar: $1 \mathrm{~mm}$
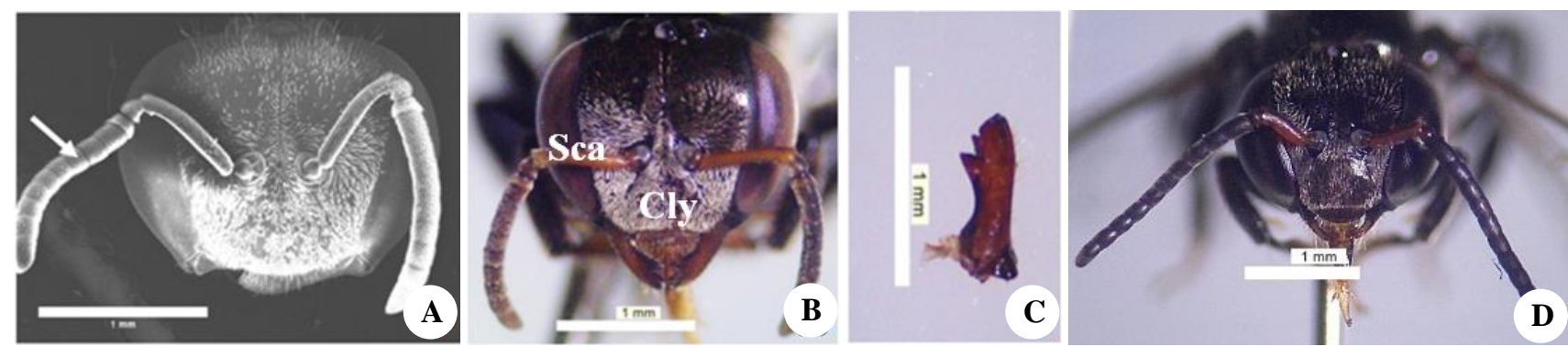

Figure 2. Head of worker stingless bee collected from Banten Province: A. Head of worker (frontal view) taken by SEM and flagellomere-IV (indicated by arrow), B. Clypeus (Cly) and scape (Sca), C. Mandible with two teeth, d. head of male (frontal view). Scale bar in each figure: A, B, C, D: $1 \mathrm{~mm}$ 
Table 1 Morphometrics characters of worker stingless bee collected from Pandeglang, Banten Province ( $\mathrm{n}=30$ individuals)

\begin{tabular}{|c|c|c|}
\hline \multirow{2}{*}{ Body characters } & \multicolumn{2}{|l|}{ Length (mm) } \\
\hline & Min. Max. Mean & SD \\
\hline Body Length (BL) & 4.3054 .5884 .445 & 0.072 \\
\hline Head Length & 1.5411 .6001 .558 & 0.013 \\
\hline Head Width (HW) & 1.8721 .9591 .911 & 0.019 \\
\hline Mandible Length & 0.7230 .7630 .738 & 0.009 \\
\hline Mandible Width & 0.2210 .2660 .245 & 0.012 \\
\hline Clypeus Length & 0.4820 .4880 .482 & 0.001 \\
\hline Lower Interocular Distance & 0.9651 .0050 .979 & 0.009 \\
\hline Upper Interocular Distance & 1.0151 .1741 .124 & 0.037 \\
\hline Eye Width (EW) & 0.4600 .4950 .470 & 0.008 \\
\hline Eye Length (EL) & 1.2871 .3041 .302 & 0.005 \\
\hline Maximum Interorbital Distance (MOD) & 1.2911 .3361 .305 & 0.008 \\
\hline Lower Interorbital Distance (LOD) & 0.9951 .0201 .010 & 0.006 \\
\hline Interantennal Distance & 0.1910 .1960 .193 & 0.003 \\
\hline Interocellar Distance (IOD) & 0.3760 .3810 .376 & 0.001 \\
\hline Ocellocular Distance (OOD) & 0.2800 .2850 .281 & 0.001 \\
\hline Antennocellar Distance & 0.7380 .7680 .763 & 0.006 \\
\hline Antennocular Distance & 0.3010 .3160 .308 & 0.005 \\
\hline Gena Width (GW) & 0.2730 .3080 .282 & 0.009 \\
\hline Length of Flagellomere IV (FL) & 0.1200 .1210 .120 & 0 \\
\hline Width of Flagellomere IV (FW) & 0.1400 .1410 .140 & 0 \\
\hline Malar Length (ML) & 0.0470 .0480 .047 & 0 \\
\hline Mesoscutum Length & $0.958 \quad 1.0280 .985$ & 0.016 \\
\hline MesoscutumWidth & 1.2041 .2181 .212 & 0.007 \\
\hline WL1 & 4.3054 .6354 .481 & 0.068 \\
\hline WL2 & 1.3001 .3271 .307 & 0.006 \\
\hline Fore Wing Length & 4.0704 .4244 .265 & 0.081 \\
\hline Fore Wing Width & 1.3391 .5821 .493 & 0.056 \\
\hline Hind Wing Length & 2.7032 .9412 .855 & 0.053 \\
\hline Hind Wing Width & 0.6640 .7880 .732 & 0.040 \\
\hline Hamuli Number & 5 & \\
\hline Hind Femur Length & 1.2011 .2661 .239 & 0.018 \\
\hline Hind Tibia Width (HTW) & 0.5270 .6230 .581 & 0.021 \\
\hline Hind Tibia Length (HTL) & 1.7031 .7731 .730 & 0.019 \\
\hline Hind Basitarsus Width (HTB) & 0.3160 .3460 .324 & 0.007 \\
\hline Hind Basitarsus Length & 0.6380 .6880 .668 & 0.013 \\
\hline
\end{tabular}

Table 2. Ratio of several characters of worker stingless bee examined ( $\mathrm{n}=30$ individuals) compared to other references

\begin{tabular}{lcccc}
\hline $\begin{array}{l}\text { Ratio of } \\
\text { characters }\end{array}$ & $\begin{array}{c}\text { This } \\
\text { study }\end{array}$ & $\begin{array}{c}\text { Manarudin } \\
(\mathbf{2 0 1 9 )}\end{array}$ & $\begin{array}{c}\text { Karimah } \\
\mathbf{( 2 0 1 7 )}\end{array}$ & $\begin{array}{c}\text { Sakagami } \\
\mathbf{( 1 9 7 8 )}\end{array}$ \\
\hline WL2/HW & 0.68 & 0.72 & 0.68 & 0.73 \\
HTL/HW & 0.91 & 0.90 & 0.93 & 0.98 \\
HTL/WL2 & 1.32 & 1.26 & 1.37 & 1.39 \\
EL/MOD & 0.99 & 0.88 & 0.97 & 0.99 \\
LOD/MOD & 0.77 & 0.76 & 0.75 & 0.75 \\
IOD/OOD & 1.34 & 1.42 & 0.67 & 1.54 \\
GW/EW & 0.60 & 0.71 & 0.61 & 0.74 \\
ML/FW & 0.34 & 0.31 & 0.32 & 0.30 \\
FL/FW & 0.86 & 1.00 & 0.75 & 0.92 \\
HTW/HTL & 0.34 & 0.33 & 0.29 & 0.35 \\
HBW/HTW & 0.56 & 0.60 & 0.59 & 0.57 \\
\hline
\end{tabular}

Mesoscutum of thorax has distinct hair bands, separated by glabrous interspaces area (Figures 3.A-B). Hairs color on the mesoscutellum fringe is testaceous to ferruginous with admixture of dark bristles. Tegula is blackish-brown to black, mesoscutellum is projecting backward (Figure 3.D), and mid- propodeum is smooth and shiny (Figure 3.C). Anterior veins and stigma of worker of the stingless bee are testaceous to fuscous (dark brown, approaching black). The number of hamuli is consistently five (Figure 5.A). Length of forewing including tegula is $4.481 \pm 0.068$ $\mathrm{mm}$ and distance between $\mathrm{M}-\mathrm{Cu}$ bifurcation and the basal tip of the marginal cell is $1.307 \pm 0.006 \mathrm{~mm}$ (Figure 5.B). Hind tibia length of worker is $1.730 \pm 0.019 \mathrm{~mm}$ (Figure 5.C) and the trochanter is testaceous. Femur, hind tibia, and hind basitarsus are blackish brown to black (Figure 5.D). Hind tibia is consistent with plumose hairs and hind basitarsus has a disc (Figure 5.E). Hairs on the fringe of hind tibia and hind basitarsus are brown to black.
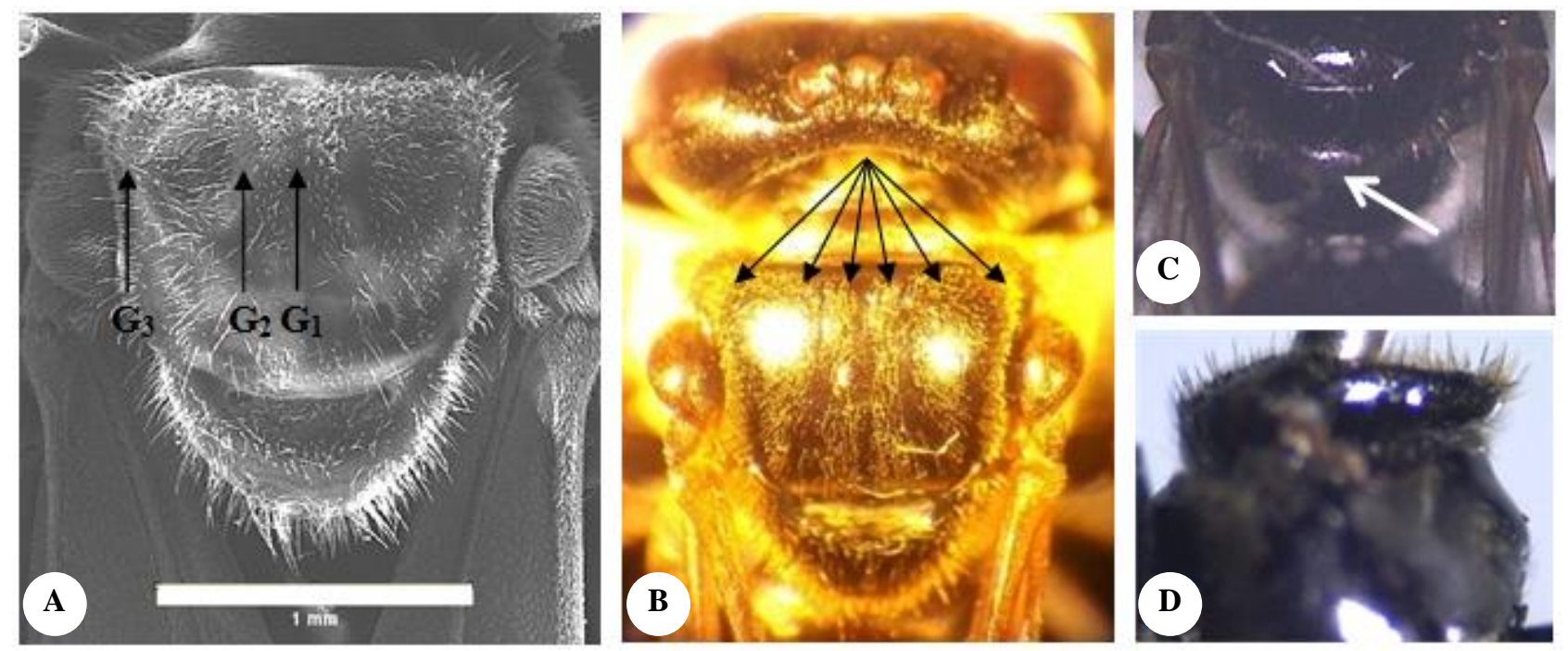

Figure 3. Thorax of worker stingless bee examined: A. Mesoscutum with glabrous interspaces area $(\mathrm{G}=$ glabrous) $(\mathrm{SEM}$ image), $\mathrm{B}$. Mesoscutum seems a distinct hair bands well, C. Propodeum is smooth and shiny, and D. Mesoscutellum is projecting backward. Scale bar in figure A: $1 \mathrm{~mm}$ 


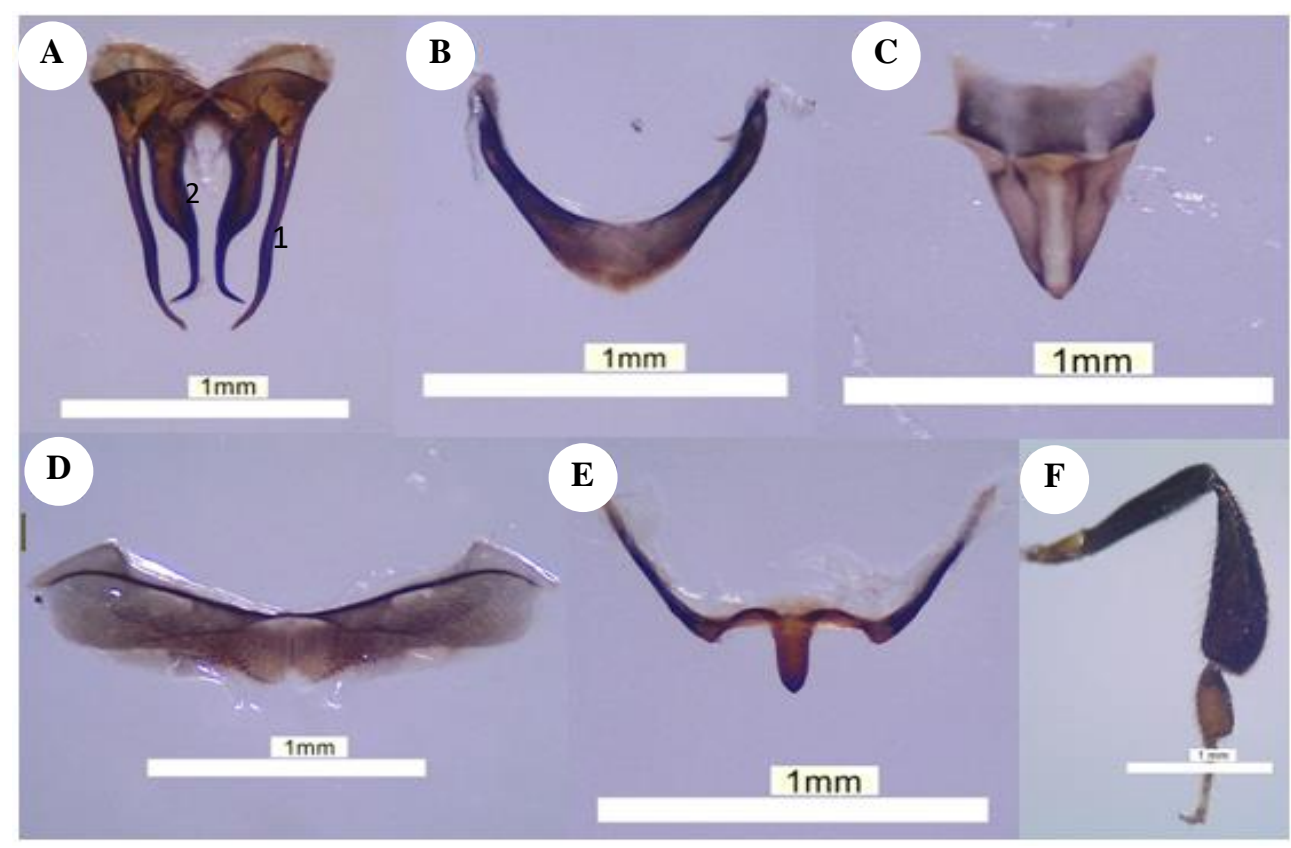

Figure 4. Characters of males stingless bee examined: A. Genitalia organ consist of gonostylus (1) and penis valve (2) (dorsal view), B. Metasomal tergum VI, C. Metasomal sternum VII, D. Metasomal sternum V, E. Metasomal sternum VI, and F. Hind tibia and basitarsus. Scale bar in each figure: A-F: $1 \mathrm{~mm}$

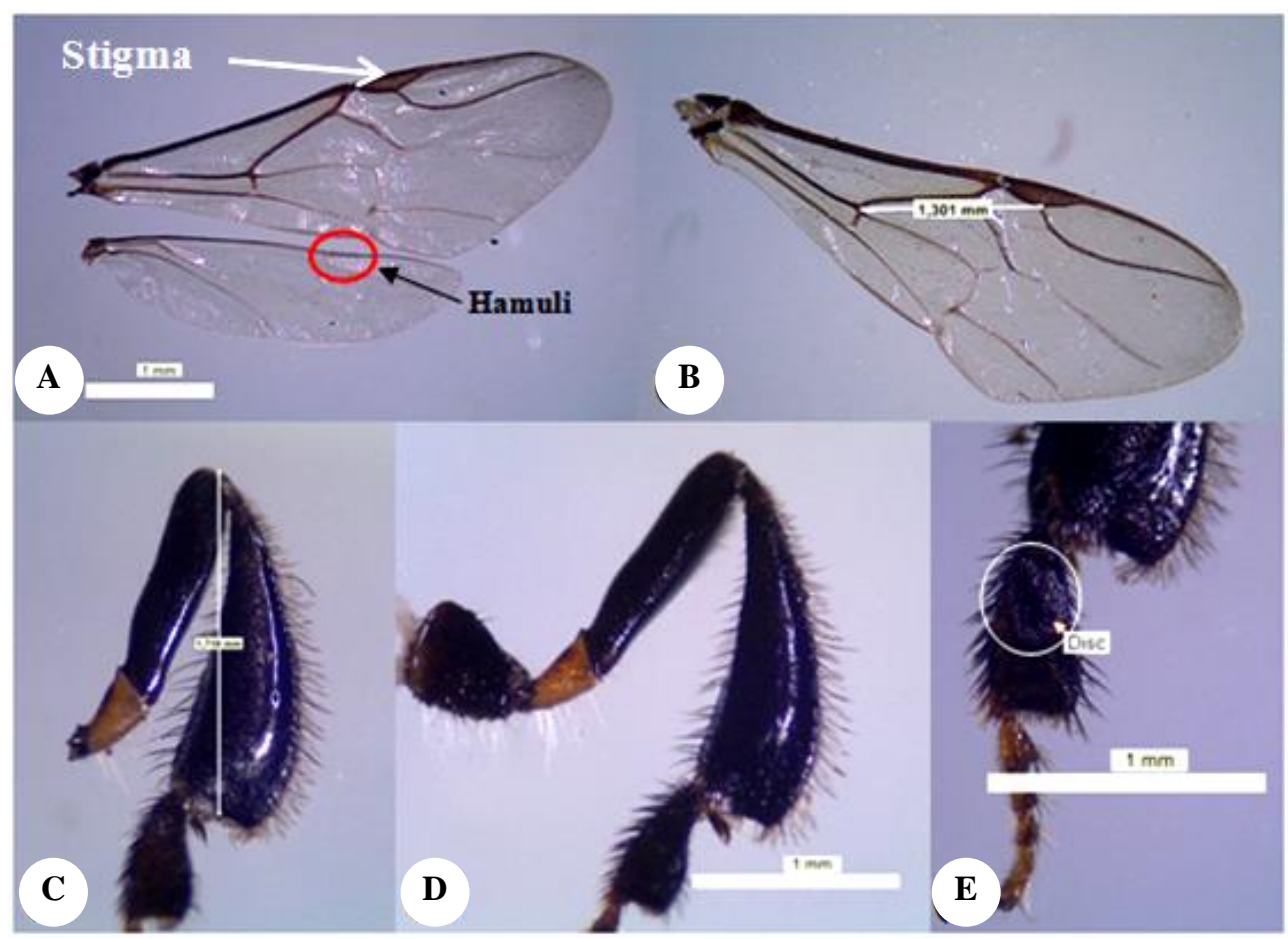

Figure 5. Wing and legs of worker stingless bee examined: A. Stigma testaceous to fuscous; the number of hamuli is consistently five, B. $\mathrm{WL}_{2}$ (distance between $\mathrm{M}-\mathrm{Cu}$ bifurcation and basal tip of marginal cell), C. HTL (hind tibia length), D. Hind femur, trochanter, tibia and basitarsus, and E. Hind basitarsus has a disc. Scale bar in each figure: A-E: $1 \mathrm{~mm}$

Genitalia structure of male stingless bee is valuable for species description (Sakagami 1978). The male genitalia has long gonostylus and slender, with sparse hairs at apex. Penis valve is very robust, tapering at the apex, and slightly shorter than gonostylus (Figure 4). Nest entrance of stingless bee examined are wet and sticky to protect the nest from predators. Interior of the nest consists of three major components, such as honey pots, pollen pots, and brood cells (Figure 6). 


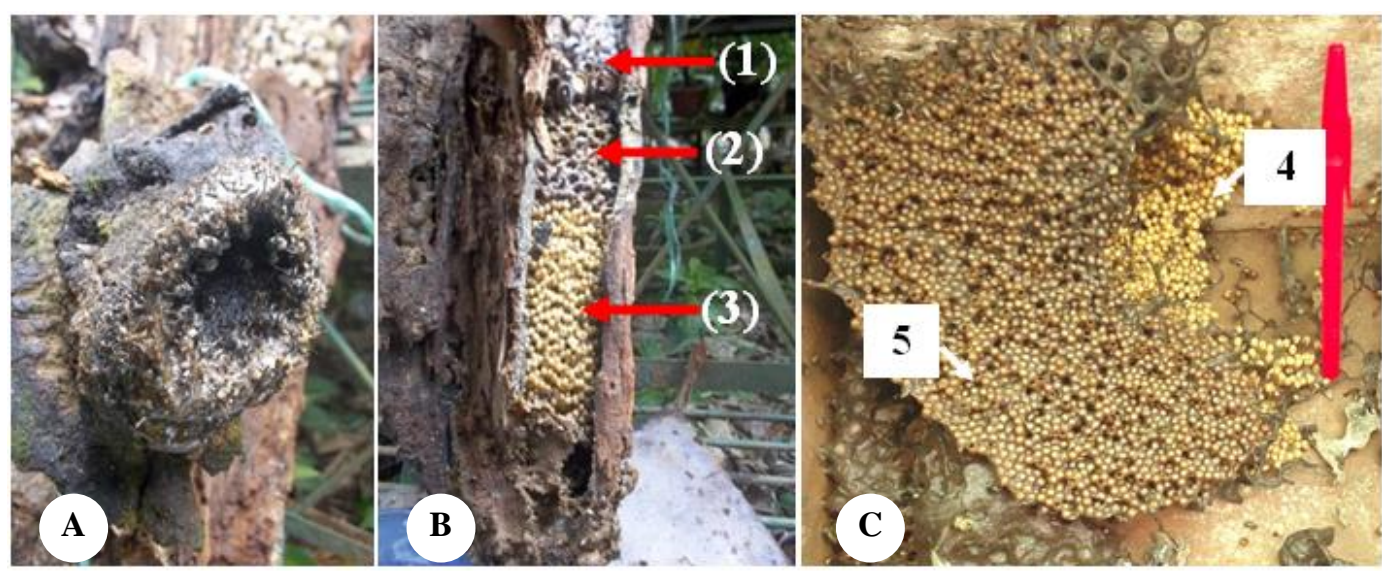

Figure 6. Nest structure of stingless bee examined: A. Nest entrance, B. Interior of the nest: honey pots (1), pollen storage (2), eggs storages (3), C. Brood cells (4 and 5)

\section{Discussion}

Based on the characters described, the stingless bee belongs to the genus Tetragonula as described by Sakagami et al. (1990) and Sakagami (1978). Those characters are a fringe of hind tibia is covered mostly by plumose hairs, a disc is on hind basitarsus, mandible is with two teeth, the mid part of propodeum is smooth and shiny, mesoscutellum is clearly projecting backward, and malar space is shorter than half the width of flagellomere II (Figure 3.A), flagellomere length is shorter than its width, flagellomere II is slightly longer than the first segment, and it has five number of hamuli.

Tetragonula cf. laeviceps observed has distinct hair bands in mesoscutum and has a larger body size than $T$. laeviceps on average. A distinct hair band in Tetragonula cf. laeviceps observed is different with $T$. laeviceps reported by Sakagami et al. (1990) there are without hairs (glabrous) in the mesoscutum, and specifically in the lateral is not flashy nor visible. The abdomen of T. laeviceps is ferruginous (Smith 1857) and the frontal hairs are not plumose (Sakagami 1978). Body size of the specimen is larger than T. minor and T. pagdeni and smaller compared to T. hirashimai. Tetragonula pagdeni has a silvery gray color on the anterior corbicular fringe, whitish frontal hairs, and their metasoma and legs are relatively pale. The male genitalia structure of the specimen is different with $T$. hirashimai (Sakagami 1978; Sakagami and Inoue 1987) and T. iridipennis (Sakagami 1978; Sakagami and Inoue 1987), but similar with T. minangkabau. But, the other characteristics of the male body of the specimen are different from T. minangkabau (Sakagami and Inoue 1985). Moreover, T. minangkabau body size is smaller than the specimen and bicolorous.

Sakagami et al. (1983) reported that the structure of nest entrance in stingless bees cannot be used as the benchmark for the identification of species. This is due to the entrance of the hive can change according to the situation and condition of the environment. Sakagami (1978) also reported that the main difficulty in the identification of Tetragonula is that there are not typical characteristics that can be relied upon as differentiator between worker bees. As a result, the classification must depend on the size, proportion, coloration, and pilosity (associated with hair). The characters sometimes are difficult or often impossible to be observed. Morphological characters are not fully able to identify the species correctly; it needs additional data, such as molecular analysis data to identify at the species level.

In conclusion, characteristics of worker of stingless bees examined are predominantly black, $4.445 \pm 0.072 \mathrm{~mm}$ body length, and $1.911 \pm 0.019 \mathrm{~mm}$ head width, and mesoscutum has distinct hair bands. Male genitalia structure of stingless bee examined are long gonostylus, penis valve is very robust, tapering and shorter than gonostylus. Nest entrance texture of the colony was wet and sticky, brood cells structure is a cluster. Based on the morphological characters and morphometric measurements, the stingless bee was identified as Tetragonula cf. laeviceps.

\section{REFERENCES}

Karimah KN. 2017. Morfologi dan struktur sarang Tetragonula laeviceps (Apidae: Meliponinae) asal Subang dan Sukabumi, Jawa Barat [Hon. Thesis]. Institut Pertanian Bogor, Bogor. [Indonesian]

Manarudin MF. 2019. Morfologi dan morfometri lebah tanpa sengat (Apidae: Meliponinae) asal Pandeglang, Banten [Hon. Thesis]. Institut Pertanian Bogor, Bogor. [Indonesian]

Klakasikorn A, Wongsiri S, Deowanish S and Duangphakdee O. 2005. New record of stingless bees (Meliponini: Trigona) in Thailand. Nat Hist J Chulalongkorn Univ 5 (1): 1-7.

Michener CD. 2007. The Bees of the World. 2nd ed. Johns Hopkins Univ. Pr., Baltimore, US.

Michener CD. 2013. The Meliponini. In: Vit P, Pedro SRM, Roubik DW (eds.). Pot-Honey: A Legacy of Stingless Bees. Springer, New York.

Rasmussen C. 2013. Stingless bees (Hymenoptera: Apidae: Meliponini) of the Indian subcontinent: diversity, taxonomy and current status of knowledge. Zootaxa 3647 (3): 401-428. 
Sakagami SF. 1978. Tetragonula stingless bees of the continental Asia and Sri Lanka (Hymenoptera, Apidae). J Fac Agric Hokkaido Univ 21 (2): $165-247$.

Sakagami SF, Inoue T, Yamane S, Salmah S. 1983. Nest architecture and colony composition of the Sumatran stingless bee Trigona (Tetragonula) laeviceps. Kontyû 51 (1): 100-111.

Sakagami SF, Inoue T. 1985. Taxonomic notes on three bicolorous Tetragonula stingless bees in Southeast Asia. Kontyû 53 (1): 174189.

Sakagami SF, Inoue T. 1987. Stingless bees of the genus Trigona (subgen Trigonella) with notes on the reduction of spatha in male genitalia of the subgenus Tetragonula (Hymenoptera, Apidae). Kontyû 55 (4): 610-627.

Sakagami SF, Inoue T, Yamane S, Salmah S. 1989. Nests of the Myrmecophilous stingless bee, Trigona moorei: how do bees initiate their nest within an arboreal ant nest? Biotropica 21 (3): 265-274.
Sakagami SF, Inoue T, Salmah S. 1990. Stingless bees of central Sumatra. In: Sakagami SF, Ohgushi R, Roubik DW (eds.). Natural History of Social Wasps and Bees in Equatorial Sumatra. Hokkaido Univ. Pr., Sapporo, Japan.

Slaa EJ, Chaves LAS, Malagodi-Braga KS, Hofstede FE. 2006. Stingless bees in applied pollination: practice and perspectives. Apidologie 37 (2): 293-315.

Smith F. 1857. Catalogue of the hymenopterous insects collected at Sarawak, Borneo; Mount Ophir, Malacca; and at Singapore, by A. R. Wallace. J Proc Linn Soc 2: 42-88.

Starr CK, Sakagami SF. 1987. An extraordinary concentration of stingless bee colonies in the Philippines, with notes on nest structure (Hymenoptera: Apidae: Trigona spp.). Insectes Sociaux 34 (2): 96107.

Vijayakumar K, Jeyaraaj R. 2014. Taxonomic notes on stingless bee Trigona (Tetragonula) iridipennis Smith (Hymenoptera: Apidae) from India. J Threat Taxa 6 (11): 6480-6484. 